\title{
Those Who Never Make It and the Suffering of Those Left Behind: The Fate of Honduran Missing Migrants and their Families
}

\section{Elisabeth Kirchbichler}

Latin American and Caribbean Studies, Utrecht University. Willibaldstr.130, 80689 München, Alemania, Phone: +491709269378. E-mail: Lisa.Kirchbichler@hotmail.com

\section{Received: July, 2010 / Accepted: September, 2010}

Every DAY HoNDURANS LEAVE THEIR COUNTRY TO MIGRATE TO THE U.S undocumented, risking their lives on the journey. Some reach the U.S.; many are deported after being picked up by either the Mexican or the U.S. authorities. This article focuses on a little acknowledged third group, those who go missing on the trip, and their families, who are left worrying and wondering what has happened. It looks at the cases of four missing migrants in the area of El Progreso, in north-western Honduras, considering what is at the root of their decision to migrate, what is suspected to have happened to them, how the situation is affecting their families and what the latter do to find them. It also examines the support they receive. These relatives are affiliated with a self-help committee founded with the aim of finding out what has happened. In the process of doing so, the committee has not only been able to locate some of those missing and put the topic on the public and political agenda in Honduras, its most active members have gained a previously unknown confidence in their ability to take the outcome of their lives into their own hands.

Key words: Missing Migrants / Honduras / Undocumented Migration / Families of Migrants

Los que nunca llegan y el sufrimiento de los que se quedan: el destino de migrantes hondureños desaparecidos y de sus familiares

Cada día, hondureños salen de su país para migrar a los Estados Unidos de manera indocumentada, arriesgando sus vidas durante el viaje. Algunos llegan a los Estados Unidos, muchos son deportados tras ser detenidos por las autoridades mexicanas o estadounidenses. Este artículo se enfoca en un tercer grupo poco reconocido, los que desaparecen durante el viaje, y sus familiares, quienes se quedan preocupados y queriendo saber qué pasó. Se examinan los casos de cuatro migrantes desaparecidos en el área de El Progreso, en el noroccidente de Honduras, considerando lo que hay en las raíces de su decisión de migrar, qué se supone que ha pasado a ellos, 
de qué manera la situación está afectando a sus familiares y qué hacen éstos para encontrarles. También examina el apoyo que reciben. Todos los familiares están afiliados con un comité de auto-ayuda creado con la meta de investigar qué sucedió a los desaparecidos. En el proceso, el comité no sólo ha encontrado a algunos desaparecidos y ha logrado poner el tema en la agenda política y pública de Honduras, los miembros más activos también adquirieron una nueva confianza en su habilidad de tomar su vida en sus propias manos.

Palabras clave: migrantes desaparecidos / Honduras / migración indocumentada / familiares de migrantes

\section{Introduction}

"It felt like my head had been ripped off". Toya struggled not to get emotional telling me about the time in 2004 when her husband Lando had gone missing while trying to reach the U.S. as an undocumented migrant and her families' search efforts remained unsuccessful. She added: "Only when I joined COFAMIPRO ${ }^{1}$ I realised I was not on my own and that together we could do something” (Toya, April 29, 2010).

Each year, thousands of Central Americans leave their countries in search of better opportunities in the U.S., forming part of the millions migrating worldwide (UNDP, 2009). Most of them try to cross Mexico and into the U.S. undocumented. Many make it and many more are being caught by the authorities and returned to their home-countries. However, some never make it either to the U.S. or back home but go missing. Left behind stay desperate families, wondering what has happened.

Very little scholarly investigation exists on the topic of missing Central American migrants and their families. A few recent studies are mainly concerned with those reported missing on the U.S.-Mexican border (Reineke, 2009) or Mexican cases (Bollinger, 2009). During a stay in the region in 2009 I had learned about an organisation of affected families, COFAMIPRO, located in El Progreso, in north-western Honduras. I decided to investigate their work for my master thesis in Latin American and Caribbean Studies at the University of Utrecht. From early February to the end of May of 2010, I conducted qualitative research mainly in the form of open interviews and participant observation.

My efforts were slightly hampered by the repercussions of the military coup of June 2009 which ousted President Manuel Zelaya in favour of the president of the senate, Roberto Micheletti. Civil society activities largely grinded to a halt, as many foreign donors froze their aid and activities became difficult given the violence and occasional imposition of curfews. A third contender, Porfirio Lobo, was elected new president in a much contended general election in November 2009. Upon my arrival in February 2010, things were on the road to recovery but still not back to their previous level.

The aim of my research was to approach the fate of missing migrants and their families in a holistic way looking at three aspects: The decision to leave and its impact; the reactions and 
coping process of the relatives once the migrant is missing; and the communal action taken through COFAMIPRO and the support they receive.

I focused on four families affiliated with COFAMIPRO, those of Ada, Lando, Rosita and Tachito. Further information came from voluntaries and NGOs supporting the families, especially from Nelly, the General Secretary of the committee. Furthermore I participated in a meeting with the Foreign Ministry and interviewed with one of its representatives.

A formula used by Puerta (Sladkova, 2007), 'decision to emigrate = expulsion + attraction $>$ costs + risks' helps explain the process of deciding to leave. The expulsion factors at home and the attraction of the destination have to be perceived stronger than the potential costs and risks connected to it. The hope to improve the economic standing of their families through sending remittances is at the root of most migrants' decision (Narayan, Pritchett $\&$ Kapoor, 2009). The consequences of the separation are among the prime costs (Falicov, 2003) and the dangers of the journey the prime risk.

When a migrant goes missing, relatives experience an incomplete, ambiguous loss (Boss, 1999), since the person is absent but it is not clear what has happened. Amnesty International (1981) suggests three stages of response by the families, where a first phase of initial inaction is followed by obsessive search before some relatives eventually move on to engage in collective action. For the portrayed families, I find it necessary to enhance this with another phase of prolonged inaction following the obsessive search. The relatives feel unable to confront the situation in a proactive way because of the small degree of control they perceive to have over their lives (Narayan et al., 2009). Many are only taking initiative after joining other affected relatives in organisations like COFAMIPRO.

The last perspective deals with this stage, when relatives organise to take action. It finds that even though the search-efforts might not be as successful as hoped for, the activities have the positive effect that the relatives find their voice, raise their self-esteem and become more aware of their rights. It also deals with the consequences of a reappearance or determination of a migrant's fate, which can release relatives from the uncertainty but often raises other concerns within the family.

\section{Taking the Decision to Leave}

Migration has existed throughout history, both internally, as 'human movement within the borders of a country', and internationally, as 'human movement across international borders'. The fate of missing migrants is closely tied to undocumented international migration, where the person has no official permission to enter and or work in the country of destination, a condition an estimated 50 million people worldwide currently find themselves in (UNDP, 2009).

When a person is making the decision to emigrate to another country, the already mentioned formula used by Puerta (Sladkova, 2007) applies:

Decision to emigrate $=$ expulsion + attraction $>$ costs + risks 
For citizens of developing countries, this often comes out in favour of international migration. Mostly there is a combination of expulsion factors, but the dire economic situation of their families is often the most powerful. This also applies for Central America. Migration from this region to the U.S. has long existed but rose sharply during the civil wars of the 1980s and was kept high by a series of natural disasters (ECLAC, 1999).

Honduras was spared the armed conflict of its neighbours but was struck by hurricane Mitch in 1998. Over half of its population is currently living under the poverty line (UNDP, 2009). There is little agreement on the numbers of Hondurans leaving the country annually, ranging from 80,000 (Sladkova, 2007) to 185,000 (Zavala, 2007), but only about a quarter actually makes it to the U.S. Remittances account for 20 percent of Honduras' GDP (Migration Policy Institute, 2010); about a third of all households receives them (Orozco, 2008).

My research area, El Progreso, was especially hardly hit by the consequences of Mitch, affecting the livelihoods of nearly three quarters of the population (ECLAC, 1999). Before, the economy mainly depended on banana plantations owned by the United Fruit Company, most of which were destroyed (ECLAC, 1999). Production was reoriented toward more resistant and less labour intensive African palm (Barahona, Posadas \& Ruiz, 2009). Suddenly, many people had lost their homes and were out of work, causing a collective trauma still noticeable. Especially men struggle to find stable work. Young people find employment in maquila manufacturing outlets, facing bad working conditions. Untrained, most are unable to maintain the employment beyond their thirties (Wolseth, 2008). This lack of opportunities has resulted in high levels of undocumented migration to the U.S.

Poverty is the overarching expulsion factor over all cases portrayed here. Lando's family did not lack the basic means of survival but had not enough to afford university studies for their daughters (Toya, April 29, 2010). Like many parents, Lando and Toya were willing to sacrifice to give their children an education providing a path out of poverty (Narayan et al., 2009). In Ada's case, her family struggled economically and she was sent to help in the household of relatives aged 13, where she was raped and became pregnant (Emeteria, February 23, 2010). Members of COFAMIPRO indicated she might have blamed her mother Emeteria for this. ${ }^{2}$ It appears likely that this emotional baggage made life far away in the U.S. very appealing. Rosita also left a household of dire poverty. As the oldest daughter, she wanted to help her mother Edita and dreamt of building a house for herself (Edita, March 23, 2010). On the other hand, Tachito comes from a farmer's family. His parents never thought of migration and found it unnecessary that their children did either, stressing the importance of family unity. ${ }^{3}$ They are an example of the notion that "families stand out as the most important institution in people's lives" (Narayan et al., 2009, p.282). Since Tachito had not discussed his decision, nobody is sure why he left. One of his brothers suspects unpaid debts. ${ }^{4}$ Wolseth (2008, p.331) suggests that for young men in the El Progreso area, "the United States stand in for any type of utopia where their immediate problems no longer exist".

All had seen what a difference receiving remittances makes. Like in other poor regions, in El Progreso having a relative abroad is often "a key factor distinguishing those on the higher steps of the ladder of life" (Narayan et al., 2009, p.287). Nelly, COFAMIPRO's executive 
secretary, has two sons who migrated undocumented to Florida in 2006, providing for their parents and youngest sister. The family does not have to suffer from hunger, lives in a wellkept house and can afford medical aid. ${ }^{5}$ Edita, Rosita's mother and deputy secretary of the committee, only barely survives by providing basic medical aid to friends and neighbours. Five of her children live in the U.S. undocumented but send little remittances. The US\$ 50 sent for mother's day included transaction fees, which meant less than US\$ 40 were paid out to Edita. When one of her sons called, he told her: "You know, mami, this is money to set aside for tough times". ${ }^{6}$ Nelly's household confirms the positive impact remittances have on easing daily life but Edita's case illustrates that not all migrants feel compelled to send them, often driving the remaining family into even more dire poverty (Narayan et al., 2009). Falicov (2003) traces the responsibility for those left behind to the migrants' upbringing in countries that favour collectivistic narratives about the family, including an internalized obligation to help extended kin.

The destination country might attract by offering job opportunities, higher wages and standard of living or simply the absence of the mentioned expulsion factors (UNESCO, 2005). For many Hondurans, in the U.S. awaits a network of relatives and friends to help them get started (Sladkova, 2007). Apart from Ada, all had someone to go to. Lando knew he could count on the support of his wife Toya's sibling. Rosita had relatives there; Tachito had his oldest brother.

Weighing heavily on the cost side is the separation which turns migration into a mixed blessing, deeply impacting both sides (Nayaran et al., 2009). Most migrants remain torn between the opportunities and gains in the new place while missing those left behind (Falicov, 2003). Back home, gratitude for a better economic standing through remittances is countered by a sense of loss, preoccupation and mixed feelings towards those away.

Risks depend greatly on the form the migration takes. Most of the undocumented Central Americans are little prepared when starting their journey (Amnesty International, 2010; Nazario, 2007). They can hardly be blamed as there are too many unforeseeable factors. In Mexico, they are exposed to assault, abduction, violence, rape, human trafficking and forced prostitution (Amnesty International 2010). Rosita lost her brother during a raid by the Mexican migration authorities and ended up being sold to a bar owner, but managed to flee before further harm could be done to her (Edita, March 23, 2010). Some migrants fall of freight trains they board to travel quicker (Gorney, 2008).

Most cross the U.S. border in remote and hostile areas to avoid the increased security measures, risking death by dehydration, heat-strokes and other hazards (Guerette, 2007). Lando was last seen with a group of migrants and a coyote ${ }^{7}$ on his way to cross the border in a desert area. The coyote later refused to explain what happened and the family assumes he died in the desert (Toya, April 29, 2010). There has been no coordinated effort along the U.S.-Mexico border to register cases of missing migrants or count the recovered remains of those believed to be migrants (Reineke, 2009). What easily gets out of sight when talking about missing migrants is that to every case there is a heavily affected family. 


\section{Realising a Migrant is Missing}

For all those problems to occur, the migrant has to actually make it to the U.S. But when they left, their families were prepared not to be constantly in touch with them for some time. Therefore, it took them a while to suspect something was wrong. Edita got news that Rosita's younger brother had finally made it to Houston, with no idea what had happened to his sister (Edita, March 23, 2010). Toya was told by a returning migrant he had seen her husband on his way to cross the border to the U.S. Tachito initially kept in touch regularly once he had found work in Mexico. His youngest sister recalls the last time talking to him: "He said he was moving to Cancún, where life was better. After this time, his calls just stopped and we did not know why. It was terrible”.

For the families of missing migrants, a nightmare becomes reality. A huge variety of possibilities exist as to what has happened, from death or abduction to a voluntary ceasing of contact (Reineke, 2009), making it hard to figure out what to do. At this point it is necessary to clarify the terminology. Even though the terms disappeared and missing are often used interchangeably, there is an important difference in the Latin American context. Disappearance is associated with missing persons after being apprehended by government agents or people acting in some form of collusion with them (Amnesty International, 1981). For missing persons, such official involvement is not given. In any case, nothing remains the same for the families (Trully, 1995).

According to Boss (1999) the families experience ambiguous loss -an incomplete or uncertain form of loss- when a relative goes missing. The person is physically absent but psychologically kept present since there is no certainty whether he is alive or dead. Edita recalls setting food aside for her daughter, just in case she would suddenly stand in the door (Edita, March 23, 2010). Most people find difficult to accept the loss of a person unless they see the body (Boss, 1999). For families of missing migrants, there is not even a clearly identifiable culprit to blame for the situation.

Since the migrants are going missing days, weeks or months after they have left, to their larger surrounding they vanish quietly. Toya dreaded encountering acquaintances asking for Lando, assuming he was in the U.S. It took her years not to well up. She recalls: "A year ago, I cried talking about him, but then I told myself I have to deal with what happened and decided no longer to avoid talking about it" (Toya, March 19, 2010).

Some families extend the internalized obligation to help kin (Falicov, 2003) to doing everything possible to find the missing alive or at least to bury the remains. In this context, Trully (1995) points out that often women are the most active, viewing their search as a logical extension of their responsibilities towards their families. This is also the case for most families portrayed here, apart from Tachito's, where the father is involved too. Tachito's youngest sister told me that she feels that what has happened has made them more united as a family. ${ }^{8}$ This concurs with the observation that "family love and unity provide the moral and psychological support that enables people to survive hard times" (Narayan et al., 2009, p.282). 
Amnesty International (1981) suggests three stages of response by families of the disappeared: initial inaction, obsessive search and collective action. In the case of the families portrayed here, these need to be extended to four, with a second phase of inaction before reaching the final stage of communal action.

In all families initial inaction was caused by the shock of realising the migrant was missing. Then, only Lando's family made an active search effort. His wife Toya's relatives in the U.S. went to search on known entry points for migrants and even hired a lawyer to find out whether he was detained. However, after months of fruitless efforts, they stopped. Tachito's family tried to get in touch with the coyote who had brought him to Mexico but the efforts remained futile too. Edita and Emeteria state that since their daughters had not paid a coyote, there was no one to get in touch with.

Then, all families fell into another stage of inaction, which in some cases lasted years and evolved from intense grief to complete resignation. Lando's wife Toya fell into a deep depression: "It felt like my head had been ripped off. I was just overwhelmed with sadness" (Toya, April 29, 2010). Fortunately none of those portrayed here was so affected that they experienced a further decline into poverty, not an unlikely possibility in such events (Narayan et al., 2009).

Asked why they did not do more, all relatives stated the same: they had no idea what to do or who to ask for help. Many retreated to their faith as the ultimate source of strength and hope left to them. Bollinger (2009) describes the intense hope that makes relatives survive the tragedy they are experiencing, nurtured by deeply rooted religiosity. Edita recalls quarrelling with God about why he was doing this to her family, pleading to him to make sure Rosita was alive (Edita, April 17, 2010). Religion offers consolation but can also contribute to a feeling of being in 'the hands of God', where one's fate is outside one's own influence, since only God can change it (Gissi, 1995).

Her statement is very much in line with the notion that many Latin American poor see their lives 'in the hands of God', depending on his mercy, and perceive a lack of control over their lives (Narayan et al., 2009). This fits with the observation of Narayan et al. (2009) that there is a relationship between shocks and the subsequent perceived lack of control over one's life. The families portrayed here emerged from the second phase of inaction only when they learned about COFAMIPRO and decided to join.

\section{Search and Support}

Returning to the three stages of response some relatives finally reach a stage where they can move on (Boss, 1999, p.127). Many resort to helping others in the same situation or working towards sparing others the experience (Reineke, 2009) joining organisations like COFAMIPRO, a pioneer organisation of families of missing migrants not only in Honduras but in the whole of Central America. It emerged in 1999 out of an initiative of Radio Progreso -a local Catholic radio station in El Progreso-, as already mentioned, the year after hurricane Mitch had hit the country with devastating consequences. COFAMIPRO was born when it became clear how significant the number of families was who did not know about 
their relatives on the way to the U.S., to find out about as many cases as possible through communal action by its members.

Over time, COFAMIPRO evolved to currently representing over 350 pendant cases of missing migrants (Nelly, February 8, 2010). The committee's roots are within the socially and politically active Catholic scene of El Progreso. The close bonds with the Catholic Church have both positive and negative effects. They limit the reach among members of evangelical churches, but the Catholic Church is one of the most active actors in providing help to migrants in Central America, Mexico and the U.S.

The committee started to stage search trips, taking photos of the missing to make their fate known and hoping for clues from the local population. During the first two, to Tecún Umán, a Guatemalan town bordering Mexico heavily frequented by undocumented migrants, in 2000, and to Tapachula on the Mexican side of the border with Guatemala, they found eight missing migrants. Trips in 2004 and 2006 along known migrant routes in the Mexican states of Chiapas and Veracruz and in 2008 to Mexico City generated political and press attention (Nelly, February 8, 2010)..$^{9}$ Despite having resolved very few cases, these trips are COFAMIPRO's most effective way of generating attention and have majorly contributed to put the issue on the political and public agenda in Honduras. The committee also feeds its cases into a database for missing migrants of the $\mathrm{SJM}^{10}$. However, this tool is little effective in reaching those most likely to encounter the missing, fellow migrants on the move. For a database of this kind to operate effectively it would have to be a single centralised one for all cases of missing Latin Americans, regardless of being migrants or not, which can be fed by a variety of organisations, both governmental and non-governmental and accessed by anyone.

The real achievement of COFAMIPRO lies in the psychological and emotional support offered to the relatives. Most people and institutions are not accustomed to providing support for a loss that is not certified (Boss, 1999) and the committee fills that void. It helps when the family is overwhelmed with the prolonged psychological stress and cannot provide the general climate of warmth, affection and emotional support helpful to the coping process (Walsh, 1996). Toya noted how the committee helped her out of her depression and that only by joining she realised that there were many more in her situation (Toya, March 19, 2010).

It is mostly the women who are active members. Hill Collins' (Schmalzbauer, 2004, p.1320) notion of motherwork, "the productive and reproductive labor that poor women do to ensure the survival of their children and community", and Trully's (1995) notion that the search is a logical extension of that fit into the picture.

When this internal sense of responsibility is bundled in a community of likewise affected and paired with the experience of success, like finding some of the missing, members develop unexpected self-confidence. Emeteria, Edita and Nelly state that the involvement with COFAMIPRO lifted their self-esteem and empowered them as women. ${ }^{11}$ While the search for the relatives resembles a lottery, the involvement provides all members with the sense of influence on their life important to reverse the effects of the shock experienced when a relative has gone missing (Narayan et al., 2009). After overcoming her depression, Toya started to bake sweet rolls to sell on weekends. However, it has to be kept in mind that all 
relatives of missing migrants portrayed here are fairly active in COFAMIPRO, or at least attending the monthly assemblies, taking full advantage of these aspects.

Despite all the positive aspects, there are also tensions. COFAMIPRO is slowly outgrowing its initial purpose as a voluntary self-help group of affected families. The leadership is torn between representing this ever growing group while being perceived as some of the main actors in the field of supporting undocumented migrants in Honduras, clearly stretching their capacities. However, it would be wrong to blame the problems COFAMIPRO faces on its leadership. Instead of engaging actively, many families have come to perceive the committee as a service provider rather than a self-help initiative. In the words of Nelly:

They come to us and hand in the documents about their missing relatives, often incomplete, call two weeks later and say "have you found my son?" like we only have to make one phone call and the person appears. We tell them from the beginning, we can put the case in the data base, call our contacts in Mexico and the U.S. and people can participate in the search trips. However, these trips are not so one just looks for his own relative. It is about taking care of all cases, about solidarity. That is when most people lose interest, they are not interested in a common effort but simply want someone else to solve their problems (Nelly, April16, 2010).

The effects of shocks like the missing of a relative can have such a drastic negative impact on confidence in oneself (Narayan et al., 2009) that it takes more to reverse this than the committee can offer. Still, organisations like COFAMIPRO do provide the most direct and effective support to affected relatives and are the most important link between them and other actors in civil society.

Narayan et al. (2009) note that for poor people's groups to be successful, they need outside help to overcome constraints posed by a lack of resources, knowledge and skills. The main financial and logistic support to COFAMIPRO comes from $\mathrm{ERIC}^{12}$, a social work outlet of the Jesuits. To get in touch with the relatives, COFAMIPRO makes use of a weekly radio show facilitated by Radio Progreso, Abriendo Fronteras ${ }^{13}$ (Opening Borders), moderated by Nelly and Edita.

On a national level, the committee forms part of Red COMIFAH ${ }^{14}$, a network of committees modelled after COFAMIPRO, organising joint activities such as the search trips. ${ }^{15} \mathrm{FONAMIH}^{16}$, the National Forum for Migration, unites most national actors working in the field of migration, including COFAMIPRO and Red COMIFAH. The forum provides the connection to both the government and international organisations and has contributed greatly to the recognition of the issue of missing migrants by the government (Edith Zavala, March 10, 2010). There are also efforts to connect Honduran committees with others like COFAMIDE in El Salvador, to join efforts on a regional Central American level. ${ }^{17}$

Despite all efforts from the committees, most families recognize the need for more involvement of the authorities ${ }^{18}$. Those active in civil society regularly complain about a lack of political will and accountability when it comes to supporting their work. ${ }^{19}$ An interview with one of the Chancellery's representatives unfortunately underlined this impression. ${ }^{20}$ 
For reasons of fairness it has to be said that the current government had just taken office during my research period.

After years of turning a blind eye on the fate of missing migrants and those in transit, in 2008, the government of then President Manuel Zelaya approved a law assigning 15 million Lempiras (about 800,000 US\$) annually to the newly created FOSHOMI ${ }^{21}$, a fund to help Honduran migrants in vulnerable conditions, including support to the search for the missing. However, the money has never been distributed ${ }^{22}$, something the new authorities have promised to change ${ }^{23}$, a development cautiously welcomed by those involved.

However, given the sheer number of missing migrants, the authorities do not realistically have the human and financial resources to be the main actor when it comes to finding them. What can be expected is to press for the respect of the migrant's rights by both the Mexican and U.S. governments and to play an active role in the creation of international tools like a DNA database to identify missing migrants (Amnesty International, 2010).

\section{Dealing with a Reappearance}

What is left is to look at what happens when a migrant actually does reappear. The first assumption is that the family must be happy to be released from the uncertainty. Sometimes, this is the case. However, it would be too easy to assume that in every case where there is word about the fate of a migrant, the time of pondering and doubt is over. Knowing is a relative term, as Tachito's case shows. After months of not getting in touch, the family received a call from him on his mother's birthday. Everyone was relieved. He said he was still in Mexico and fine, but insisted he would make it to the U.S. eventually. His father Anastacio remembers:

I said "Son, come home". Everyone wanted to talk to him, and he said he was calling on a phone card with limited time. Now, I think I should have insisted more, ask him for a number where to be reached (Anastacio, May 19, 2010).

For days, then weeks, the family waited to hear from him again, but Tachito did not call. They remain torn between the relief of him being alive, worried because they do not know the circumstances, and angry because he does not call again. Albeit in a changed form, they still experience ambiguous loss. His case shows the many shades of grey between not knowing anything and having certain knowledge about the fate of a person.

Edita has been told that Ada was seen alive in the U.S. (Emeteria, March 18, 2010). This has led many to think that Ada consciously does not get in touch. At times, Emeteria agrees. Sometimes, she still presents her daughter as missing. Both things are true. To her mother she is missing since she cannot make peace with the situation until she knows for sure. By continuously presenting Ada as missing to the world, Emeteria retains her last and only possibility to force her daughter into getting in touch.

Some families eventually do experience the happy reunion all hope for. In 2002, Rosita's partner recognized her on one of the photos the ladies of COFAMIPRO held into Mexican 
television cameras. An emotional reunion between mother and daughter followed: It turned out she had settled in Mexico and her letters home never reached Honduras. In 2004, Rosita became gravely ill and was brought to her mother's house for care. She died of an unidentified illness. Even though Edita was devastated by her daughter's death so shortly after finally finding her, it gives her great calm to know she is buried close to her home in Honduras. ${ }^{24}$ This is in line with Boss' (1999) theory that it is not so much the being alive and well of a person that gives the relatives peace, but even more the certainty of what is going on, a clear situation, even if this means having to face that the person is gone forever.

\section{Conclusion}

I had come to El Progreso to research missing migrants and their families, settling on three general lines: the decision of a migrant to leave and how it impacts his family, the reactions and coping process of the family once it becomes clear he is missing, and communal action taken by the relatives and the support they receive.

So far, research has dealt with missing migrants mainly as a side product of general reports on the dangers undocumented migrants face in Mexico (Amnesty International, 2010; Comisión Nacional de los Derechos Humanos, 2009), those missing on the U.S.-Mexican border (Reineke, 2009) or focused on Mexican families (Bollinger, 2009). My research looked at missing migrants and their families in a Central American context, showing that it is not enough to just look at either the migrant or his family, but that both sides are tightly linked. This applies for the whole chain of events, from the decision to migrate to the realisation that the migrant is missing, the coping process and possible communal activity until a reencounter or the acceptance that it is time to move on.

Looking at Puertas' (Sladkova, 2007) formula according to which the decision to migrate is taken when expulsion and attraction factors outweigh perceived costs and risks, my findings concur with the notion of the almost symbiotic unit most migrants and their families form (Narayan et al., 2009). The majority leaves to support their families in a bid to step out of poverty, despite the cost of family separation. This bond continues to exist even when the former has gone missing.

In this case, the families confront a situation too complicated for most of them to handle individually. They experience an uncertified, ambiguous loss (Boss, 1999). I found their reaction similar to the three stages of response described for families of the disappeared (Amnesty International, 1981), only that in this case, there are four stages: initial inaction; frantic search; prolonged inaction; and finally communal action. It became clear that the families' inaction is caused by their perceived lack of control over their lives (Narayan et al., 2009). Often relatives only start to thrive when encountering others in the same situation and find a way to engage in collective action.

The success of these actions should not be measured in the small numbers of missing migrants found. It is the experience to be able to achieve something through the own initiative that counts, something that can eventually show a path out of poverty (Narayan et al., 2009). However, the relatives are still overwhelmed with the actual search, affirming the need for the government to push for international initiatives to tackle this issue. 
Despite looking at only four families, I am convinced that the findings are applicable for most missing Central American migrants and their families, especially since much concurs with Bollinger's (2009) observations about Mexican families.

Many aspects concerning missing migrants and their families still need to be explored. Most importantly, the problem of missing migrants is not limited to Central Americans and Mexicans. Africans in deplorable conditions are being washed to the shores of Spain after trying to cross the Mediterranean in decrepit boats in a desperate attempt to make it to what they consider their promised land (Davies, 2010, April 17). Similar incidences occur anywhere in the world where people are determined to make it to a country that does not officially welcome them. To every case there is a family. So even though my research only looks at a town in Honduras, it is the larger context that matters. When there is talk about the respect of migrants' rights, the rights of their families should also be taken into account, especially since what most of them ask for is simply to know what happened.

\section{Acknowledgments}

Quiero agradecerles a los miembros de COFAMIPRO y los equipos del ERIC y de FONAMIH la ayuda que me han brindado durante mi trabajo de investigación en Honduras.

Notes

1 Comité de Familiares de Migrantes en El Progreso (Committee of Families of Migrants in El Progreso).

2 Informal conversations with members of COFAMIPRO.

3 Interview with Tachito's parents, March 4, 2010.

4 Informal conversation with several family members, May 19, 2010.

$5 \quad$ I lived with Nelly's family during my whole fieldwork.

6 Information obtained through informal conversations during visits at Edita's house.

7 Coyote is a common Central American term for persons smuggling migrants over the border for a fee.

8 Informal conversation with Tachito's sister, April 28, 2010.

9 See also, Barrera Aguirre (2008, October 16).

10 Servicio Jesuita para Migrantes (Jesuit Service for Migrants) http://www.sejemi.org/site/perdidas.php

11 Meeting with representatives of COFAMIDE, April 24, 2010.

12 Equipo de Reflexión, Investigación y Comunicación de la Compañia de Jesús (Team for reflection, investigation and communication of the Society of Jesus).

13 Sundays, 12:30 to 13:30 local time, live stream at www.radioprogresohn.net

14 Red de Comités de Migrantes y Familiares en Honduras (Network of Committees of Migrants and Families in Honduras).

15 Meeting between members of COFAMIPRO, COFAMIDE and staff of Red COMIFAH, April 25, 2010.

16 Foro Nacional de Migraciones en Honduras

17 Meeting of COFAMIPRO, COFAMIDE and Red COMIFAH, April 25, 2010.

18 Informal conversation with members of COFAMIPRO, April 25, 2010.

19 Representatives of COFAMIPRO and Red COMIFAH.

20 Interview with staff of the Chancellery, Tegucigalpa, May 11, 2010.

21 Fondo de Solidaridad con el Hondureño Migrante en Condiciones de Vulnerabilidad (Solidarity Fund for Honduran Migrants in Vulnerable Conditions)

22 Interview with Edith Zavala (FONAMIH), May 5, 2010.

23 Meeting of the Executive Council for FOSHOMI, Tegucigalpa, May 7, 2010.

24 Statement during a meeting with representatives of COFAMIDE, April 24, 2010. 


\section{References}

Amnesty International. (1981). 'Disappearances': A Workbook. New York: Amnesty International USA Publications

Amnesty International. (2010). Invisible Victims, Migrants on the Move in Mexico. London: Amnesty International Publications

Barahona, M., Posadas, O. \& Ruiz, N. (2009). Localidad y globalización en la dinámica migratoria hacia los Estados Unidos, El caso de los minicipios de El Progreso y El Negrito. Equipo de Reflexión, Investigación y Comunicación de la Compañia de Jesús en Honduras, El Progreso: Editorial Casa San Ignacio.

Barrera Aguirre, J. M. (2008, October 16). Buscan centroamericanos en Lechería a familiares migrantes, El Universal. Retrieved on June 25, 2010 from http://www.eluniversal.com. $\mathrm{mx} /$ notas $/ 547698 . \mathrm{html}$

Bollinger, S. L. (2009). The New Desaparecidos: Effects of Missing Migrants on Families of Sending Communities in Southern Mexico. Master Thesis, Graduate College, The University of Arizona

Boss, P. (1999). Ambiguous loss: learning to live with unresolved grief. Boston: Harvard University Press

Comisión Nacional de los Derechos Humanos México (2009) Informe Especial de la Comisión Nacional de los Derechos Humanos sobre los Casos de Secuestros en Contra de Migrantes. Retrieved on August 5, 2010 from http://www.cndh.org.mx/ INFORMES/Especiales/infEspSecMigra.pdf

Davies, N. (2010, April, 17). Melilla: Europe's dirty secret, The Guardian. Retrieved on August 18, 2010 from http://www.guardian.co.uk/world/2010/apr/17/melilla-migrants-euspain-morocco

ECLAC. (1999). Honduras: Assessment of the damage caused by hurricane Mitch,1998, Implications for economic and social development. Retrieved on June 25, 2010 from http://www.eclac.org/publicaciones/xml/6/15506/L367-3-EN.pdf

Falicov, C. J. (2003). Immigrant Family Processes. In F. Walsh (edt.) Normal family processes: growing diversity and complexity. 3rd ed. New York: The Guilford Press, pp.280-300

Gissi,J. (1995). Themenschwerpunkt: Armut in Lateinamerika. Gedanken zu psychologischen Aspekten der Armut. Resignation als Reaktion auf Frustration in den unteren Bevölkerungsschichten. Journal für Psychologie, 3 (1), 9-14.

Gorney, C. (2008). Mexico's Other Border. National Geographic Magazine, February 2008, Accesed on September 8, 2010 from http://ngm.nationalgeographic.com/2008/02/ mexicos-southern-border/cynthia-gorney-text.html

Guerette, R. T. (2007). Migrant Death: Border Safety and Situational Crime Prevention on the U.S.-Mexico Divide. New York: LFB Scholarly Publishing LLC

Migration Policy Institute. (2010). Remittance Profile: Honduras. Retrieved on September 8, 2010 from http://www.migrationinformation.org/datahub/remittances/Honduras.pdf

Narayan, D., Pritchett, L. \& Kapoor, S. (2009). Moving out of Poverty. Volume 2: Success from the Bottom Up. Washington DC: Palgrave Macmillan and The World Bank.

Nazario, S. (2007). Enrique's Journey. The Story of a Boy's Dangerous Odyssey to Reunite with his Mother. New York: Random House

Orozco, M. (2008). Migración y remesas en la economía de los hondureños: Sinopsis de 
los resultados de la última encuesta sobre remesas y migración realizada en Junio 2008 por Borges \& Asociados. Inter-American Dialogue Publication. Retrieved on December 8, 2008 from http://www.thedialogue.org/PublicationFiles/Encuesta\%20de\%20 Remesas\%20a\%20Honduras\%202008_08.pdf

Orozco, M. (2009). Migration and remittances in times of recession: Effects on Latin American economies, Inter-American Dialogue, April 2009. Retrieved on June 25, 2010 from http://www.oecd.org/dataoecd/48/8/42753222.pdf

Reineke, R. (2009). Borderlands of Loss: The Missing of the U.S.-Mexico Border. Paper presented at the Congress of the Latin American Studies Association, Rio de Janeiro, Brazil, June 11-14.

Schmalzbauer, L. (2004). Searching for Wages and Mothering from Afar: The Case of Honduran Transnational Families, Journal of Marriage and Family, (66), 1317-1331.

Sladkova, J. (2007). Expectations and Motivations of Hondurans Migrating to the United States. Journal of Community \& Applied Social Psychology, (17), 187-202.

Trully, S. R. (1995). A Painful Purgatory: Grief and the Nicaraguan Mothers of the Disappeared. Social Science and Medicine, 40, (12), 1597-1610. UNDP. (2009). Human Development Report 2009: Overcoming barriers: Human mobility and development. Retrieved on June 25, 2010 from http://hdr.undp.org/en/media/HDR_2009_EN_Complete.pdf

UNESCO. (2005). United Nations Convention on Migrants' Rights Information Kit. Retrieved on June 25, 2010 from http://unesdoc.unesco.org/images/0014/001435/143557e. pdf

Walsh, F. (1996). The Concept of Family Resilience: Crisis and Challenge. Family Processes, (35), 261-281.

Wolseth, J. (2008). Everyday Violence and the Persistence of Grief: Wandering and Loss Among Honduran Youths. Journal of Latin American and Caribbean Anthropology, 13, (2), 311-335.

Zavala, E. (2007). Informe Situación Migratoria Honduras 2007: Monitoreo de Violación de Derechos Humanos a Emigrantes Hondureños. Tegucigalpa: Foro nacional para las migraciones en Honduras. 